\title{
The influence of waste chromia-alumina catalyst and burning temperature on physico- mechanical properties of ceramics based on fusible clay
}

\author{
Airat Khuzin ${ }^{1, *}$, Rustem Mukhametrakhimov ${ }^{1}$, Aleksandr Lamberov ${ }^{2}$, Svetlana Egorova ${ }^{2}$ \\ ${ }^{1}$ Kazan State University of Architecture and Engineering, Zelenaya str., Kazan, 1420043, Russia \\ ${ }^{2}$ Kazan Federal University, Kremlyovskaya str., 18, Kazan, 420008, Russia
}

\begin{abstract}
Effect of waste $\mathrm{Cr} / \mathrm{Al}_{2} \mathrm{O}_{3}$ catalyst addition to fusible charge and firing temperature on the basic properties of the fired ceramics is studied. The dependence of strength, density and water absorption on firing temperature on 960,1060 and $1160^{\circ} \mathrm{C}$ is established. It is proven that increasing firing temperature up to $1160^{\circ} \mathrm{C}$ provides less leachability of $\mathrm{Cr}(\mathrm{VI})$ from samples and increased environmental safety of ceramics.
\end{abstract}

\section{Introduction}

Nowadays, eco-geological problems have acquired extremely acute due to the depletion of natural resources and degradation of terrestrial ecosystems, deterioration of the quality of the environment, which caused by rise of anthropogenic load on the environment, including waste from oil and gas industry. Therefore, the state program "Russian Energy Strategy until 2020" declares, that there is a necessity to achieve the quantity of recycling to $75 \%$ by 2020 and then to increase this amount to $85 \%$. 120 million tonnes of solid waste is annually produced in Russia, only nearly $45 \%$ is used for own production or as a secondary raw material and approximately $10 \%$ is completely detoxified.

In Russia, industrial waste (hereafter referred to as waste) according to the degree of danger in GOST 12.1.007-76 (all-Union State Standard) are divided into 4 class of hazard: I - is extremely dangerous; II - highly dangerous; III - moderately dangerous; IV low dangerous. The I group includes the following: $\mathrm{Hg}, \mathrm{HgCl}_{2}, \mathrm{~K}_{2} \mathrm{Cr}_{2} \mathrm{O}_{7}$, $\mathrm{SbCl}_{3}$, benz[a]pyrene, $\mathrm{As}_{2}$. Consequently, the first group also includes wastes from chromia-alumina catalyst, which contains $\mathrm{Cr}$ (VI).

Chromium takes the 17 th place in a abundance of elements in environment, moreover, it is nearly $0.036 \%$ of the of the Earth crustal mass.

Chromium is included in the composition of minerals called chromospinelide (or chromites), which has a general formula $(\mathrm{Fe}, \mathrm{Mg}) \mathrm{O} \cdot(\mathrm{Cr}, \mathrm{Al})_{2} \mathrm{O}_{3}$. Spinels include minerals such as chrompicotite $(\mathrm{Mg}, \mathrm{Fe}) \mathrm{Cr}_{2} \mathrm{O}_{3}$ and alumochrompicotite $(\mathrm{Mg}, \mathrm{Fe})(\mathrm{Cr}, \mathrm{Al})_{2} \mathrm{O}_{3}[1]$. Generally, compounds of tri- and sexivalent chromium get into superficial waters along of

\footnotetext{
${ }^{*}$ Corresponding author : airat.khuzin2010@yandex.ru
} 
desalination of different minerals (crocoite, chromite, uvarovite). Another natural source of chromium can be plants and other living organisms. Thus $\mathrm{Cr}$ ions can escape as a result of the decomposition of living organisms.

The main aims of prevention the chromiferous hazardous wastes in the near future are to minimize their generation. At the same time, this waste is - dissipated feedstock. Therefore, measures for reduction the generation and reclamation are fundamental, for example, they can be effectively used in the form of supplements [2-15] for adjustment the properties of various construction materials (nonfired refractory, heat-resistant porous concrete, rustinhibitive pigment, fire-resistant mastics, cement, gypsum, bituminous-concrete and ceramic compositions). In that context, assessment of the impact of waste of chromiaalumina catalyst (hereinafter CAC) (Nizhnekamsk city, Republic of Tatarstan) on physical and mechanical properties and the toxicity of the fired ceramic, which based on low-melting clay, is a topical area of research.

Finally, research proposes to develop tailored composition and technological modes of production of ecologically clean ceramic brick, which will not overshoot maximum residue limit.

\section{Materials and methods used in research}

As the main raw material used in the research fusible clay for which has been identified chemical (Table. 1) and mineralogical composition and grain size.

Table 1. Chemical composition of clay, wt. \%.

\begin{tabular}{|c|c|c|c|c|c|c|}
\hline $\mathrm{SiO}_{2}$ & $\mathbf{T i O}_{2}$ & $\mathbf{A l}_{2} \mathbf{O}_{3}$ & $\mathrm{Fe}_{2} \mathrm{O}_{3}$ & MnO & $\mathrm{CaO}$ & MgO \\
\hline 67.62 & 0.68 & 12.69 & 4.69 & 0.38 & 2.57 & 1.59 \\
\hline $\mathrm{Na}_{2} \mathrm{O}$ & $\mathbf{K}_{2} \mathbf{O}$ & $\mathbf{P}_{2} \mathbf{O}_{5}$ & $\mathrm{SO}_{3}$ & LOI & adder & \\
\hline 1.29 & 2.04 & 0.13 & 0.09 & 6.10 & 99.79 & \\
\hline
\end{tabular}

This clay is a representative sample, which is characteristic for all fusible clays used in the production of ceramic brick. This multimineral, fusible $(n=17)$ clay. Using X-ray diffraction and differential thermal analysis determined the phase composition of minerals wt. \%: Mixed - 48, hydromica - 6, chlorite - 4 quarts - 31, feldspar - 10, calcite - 1, dolomite - no. Granulation represented fractions (\%): more than $0.5 \mathrm{~mm}$ - none; 0.5 $0.25 \mathrm{~mm}$ - none; $0.25-0.1 \mathrm{~mm}-0.1 ; 0.1-0.05 \mathrm{~mm}-1.2 ; 0.05-0.01 \mathrm{~mm}-7.6 ; 0.01-0.005 \mathrm{~mm}$ - 9.9; 0.005-0.001 mm - 28.7; less than $0.001 \mathrm{~mm}-52.5$. Determination sintering showed that the water absorption rate for samples fired at $1150^{\circ} \mathrm{C}$ is $1.2 \%$, medium density -2.28 $\mathrm{g} / \mathrm{cm}^{3}$ (medium-temperature sintering). The number of types of fluxing oxides $\left(\mathrm{R}_{2} \mathrm{O}+\mathrm{RO}+\right.$ $\mathrm{Fe}_{2} \mathrm{O}_{3}$ ) in the composition is $12.2 \mathrm{wt}$. \%, and the ratio of $\mathrm{RO}: \mathrm{R}_{2} \mathrm{O}$ is in the range of $1: 1.25$.

Evaluation of the behavior of clay to show that the mineralogy and grain size determines their high sensitivity to drying and, as a consequence, low fracture toughness. Therefore, given the composition and properties of the clays, it is necessary to introduce additional materials emaciated coarsely dispersed therein.

As an additive used $\mathrm{Al} / \mathrm{Cr}$ catalyst waste (here and hereafter waste), and waste with $10 \% \mathrm{Na}_{2} \mathrm{O}$ - (here and hereafter waste $+10 \% \mathrm{Na}_{2} \mathrm{O}$ ). $\mathrm{Na}_{2} \mathrm{O}$ loaded onto waste by vacuum infiltration of moisture absorption by an aqueous $\mathrm{NaOH}$ solution. Waste characteristics shown in Table 2. 
Table 2. Characteristics of Waste.

\begin{tabular}{|l|c|c|}
\hline Parameters & Measure & Value \\
\hline Appearance & - & powder blue-green or gray-green color \\
\hline Chemical composition: & & \\
\hline - Chromium based on $\mathrm{Cr}_{2} \mathrm{O}_{3}$ & $\%$ & $10-25$ \\
\hline $\begin{array}{l}-\gamma-\mathrm{Al}_{2} \mathrm{O}_{3} \text { (gamma } \\
\text { modification) }\end{array}$ & $\%$ & $73-89$ \\
\hline - $\mathrm{K}_{2} \mathrm{O}$ & $\%$ & $1-2$ \\
\hline - $\mathrm{SiO}_{2}$ & $\%$ & $0-6$ \\
\hline - Iron impurities & $\%$ & less than $0.5-0.7$ \\
\hline - Impurity nickel, copper, zinc, & $\%$ & less than 0.2 \\
titanium & & $\mathrm{g} / \mathrm{cm}^{3}$ \\
\hline Bulk density & $\%$ & $1.3-1.5$ \\
\hline Humidity & $\mathrm{mg} / \mathrm{g}$ & $0.9-5.0$ \\
\hline The concentration of $\mathrm{Cr}(\mathrm{VI})$ & 25 \\
\hline
\end{tabular}

In this work used the standard methods of raw materials and finished products research.

Cr (VI) content was determined in accordance with TU 217341-001-38717982-2013. The determination is based on the recovery of chromium (VI) to chromium (III) and titration of liberated iodine with $\mathrm{Na}_{2} \mathrm{~S}_{2} \mathrm{O}_{3}$. The result should be the arithmetic mean of two parallel observations, rounded to the first decimal place. Absolute error of the test result $0.04 \%$, at a confidence level of $\mathrm{P}=0.95$. The strength of the samples was determined in accordance with GOST 8262-85. Water absorption and density of the samples was determined according to GOST 530-2007 "Brick and ceramic stone. General technical conditions".

\section{Experimental part}

For burning three temperature levels were selected and justified: $960^{\circ} \mathrm{C}, 1060{ }^{\circ} \mathrm{C}$ and 1160 ${ }^{\circ} \mathrm{C}$. These levels were chosen to enhance the follow pilot-scale tests developed compositions in the factories of the construction industry for the production of building ceramics, modified by the addition of waste. At temperatures $900-1000{ }^{\circ} \mathrm{C}$ traditionally been burned wall construction ceramics (solid and hollow face brick, ceramic blocks and large format ceramic stones), usually in the range $1000-1100{ }^{\circ} \mathrm{C}$ burned high-strength types of bricks and tiles, in $1100-1200{ }^{\circ} \mathrm{C}$ range - clinker bricks, ceramic tiles and expanded clay gravel.

Researches according to influence waste and (waste $+10 \% \mathrm{Na}_{2} \mathrm{O}$ ) on the physicomechanical properties and structure of ceramics burned at $960-1160{ }^{\circ} \mathrm{C}$.

By plasticizing method were produced control samples as barrels with dimensions $16 \times 16 \mathrm{~mm}$ based on fusible consisting clay modified with additives in the form of waste (waste $+10 \% \mathrm{Na}_{2} \mathrm{O}$ ), which were introduced in $0.5 ; 1.5 ; 6$ and 12 wt. $\%$ of clay from the flow. The molding humidity was $19 \%$.

Batch preparing technology is implemented in the following sequence:

1. preparation of ingredients by milling clay in a vibration ball mill for 30 seconds (the ratio of balls:material $=1: 1$ ); 
2. dosing the clay and the waste;

3. mixing the dry batch for 20 minutes in a vibration ball mill (balls: material $=1: 1$ );

4. mixing the batch to a plastic state in a step dosing water;

5. preparing test samples;

6. drying in a laboratory oven to a residual humidity of less than $4 \%$;

7. burning in a laboratory oven at $960{ }^{\circ} \mathrm{C}, 1060^{\circ} \mathrm{C}$ and $1160{ }^{\circ} \mathrm{C}$.

After preparing samples pre-dried for 24 hours in natural conditions $\left(\mathrm{t}=+20^{\circ} \mathrm{C}, \mathrm{W}=\right.$ $45-55 \%$ ), and then another 24 hours at a temperature rise from 35 to $80^{\circ} \mathrm{C}$. Compositions of batches shown in Table 3 .

Table 3. Batch composition.

\begin{tabular}{|c|c|c|c|c|}
\hline \multirow{2}{*}{ №№ } & \multicolumn{3}{|c|}{ Raw material content, мac. \% } & \multirow{2}{*}{$\begin{array}{c}\text { Burning } \\
\text { temperature } \\
{ }^{\circ} \mathrm{C}\end{array}$} \\
\hline & Clay & Waste & Waste $+10 \% \mathrm{Na}_{2} \mathrm{O}$ & \\
\hline 1 & 100 & - & - & \multirow{5}{*}{$\begin{array}{c}960 \\
1060 \\
1160\end{array}$} \\
\hline 2 & 99.5 & 0.5 & 0.5 & \\
\hline 3 & 98.5 & 1.5 & 1.5 & \\
\hline 4 & 92 & 6.0 & 6.0 & \\
\hline 5 & 88 & 12.0 & 12.0 & \\
\hline
\end{tabular}

After burning, its established the main physico-mechanical properties of samples. Then constructed graphics (Figure 1,2) which represented dependences of water absorption (Figure 1a, b), medium density (Figure 1c, d), and the compressive strength (Figure 2a, b) on the dosage level of waste and (waste $+10 \% \mathrm{Na}_{2} \mathrm{O}$ ).

a)

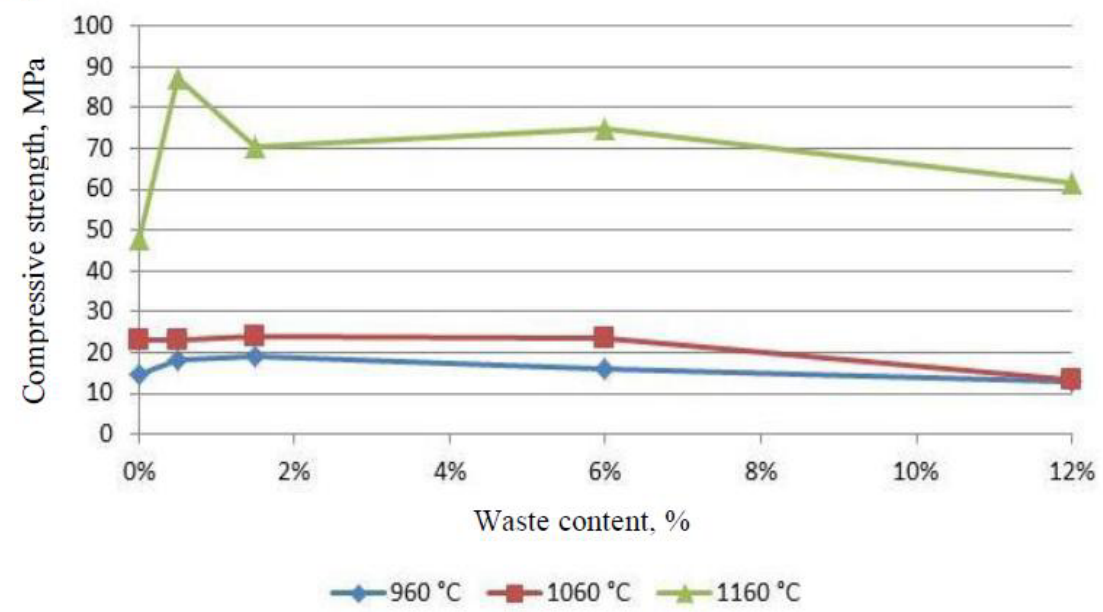

Fig. 1a. Dependences of water absorption $(a, c)$ and medium density $(b, d)$ of ceramic crock based on fusible clay on the waste and (waste $+10 \% \mathrm{Na}_{2} \mathrm{O}$ ) dosage levels and burning rate. 
b)

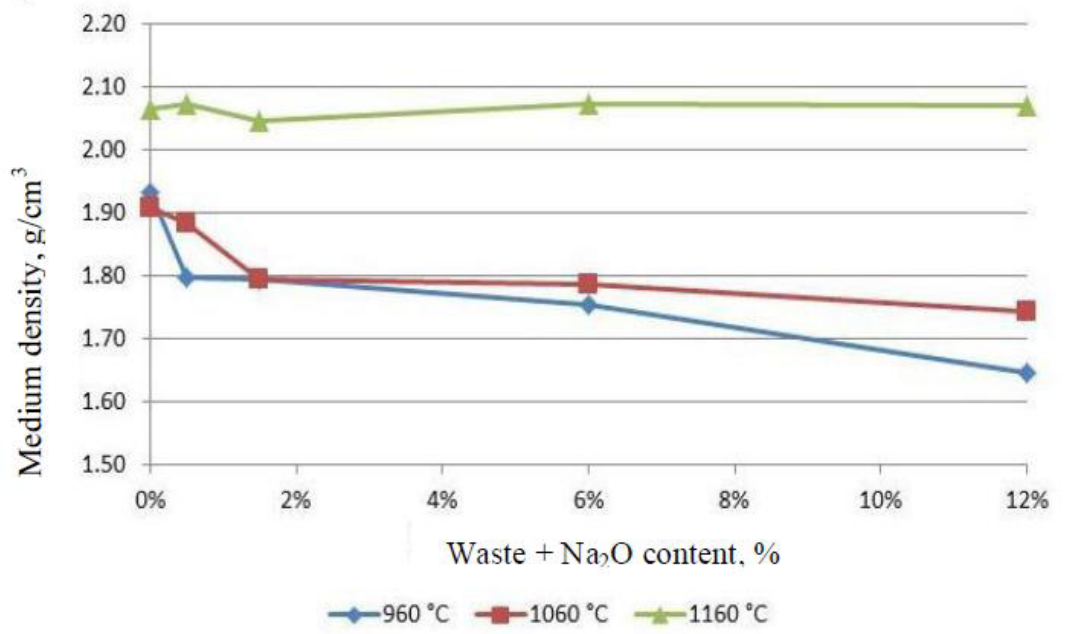

Fig. 1b. Dependences of water absorption (a, c) and medium density (b, d) of ceramic crock based on fusible clay on the waste and (waste $+10 \% \mathrm{Na}_{2} \mathrm{O}$ ) dosage levels and burning rate.

c)

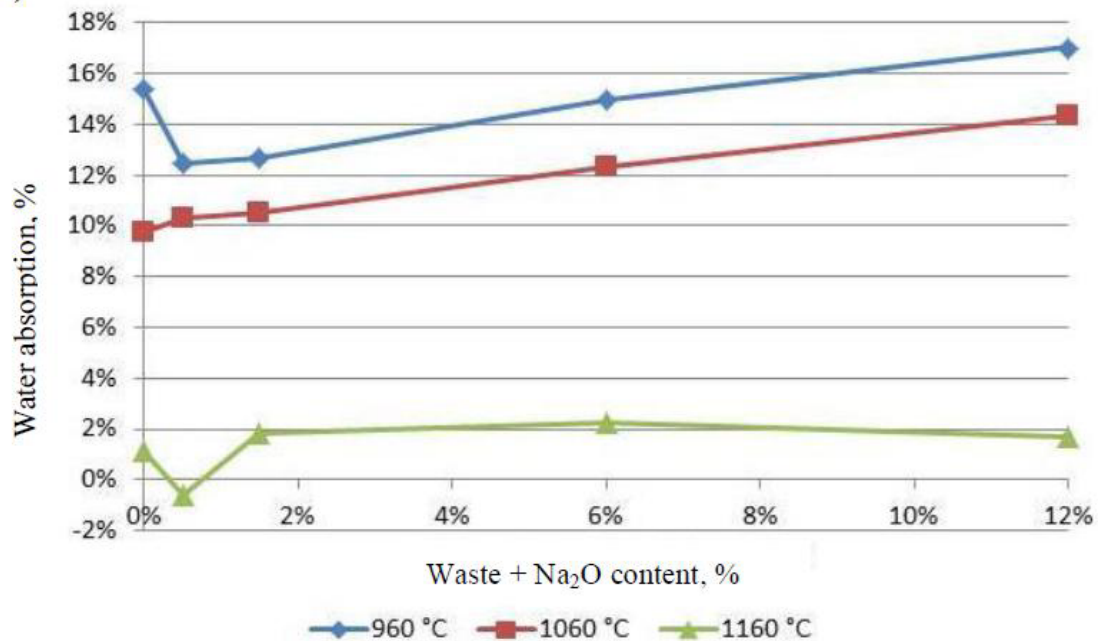

Fig. 1c. Dependences of water absorption $(a, c)$ and medium density $(b, d)$ of ceramic crock based on fusible clay on the waste and (waste $+10 \% \mathrm{Na}_{2} \mathrm{O}$ ) dosage levels and burning rate. 
d)

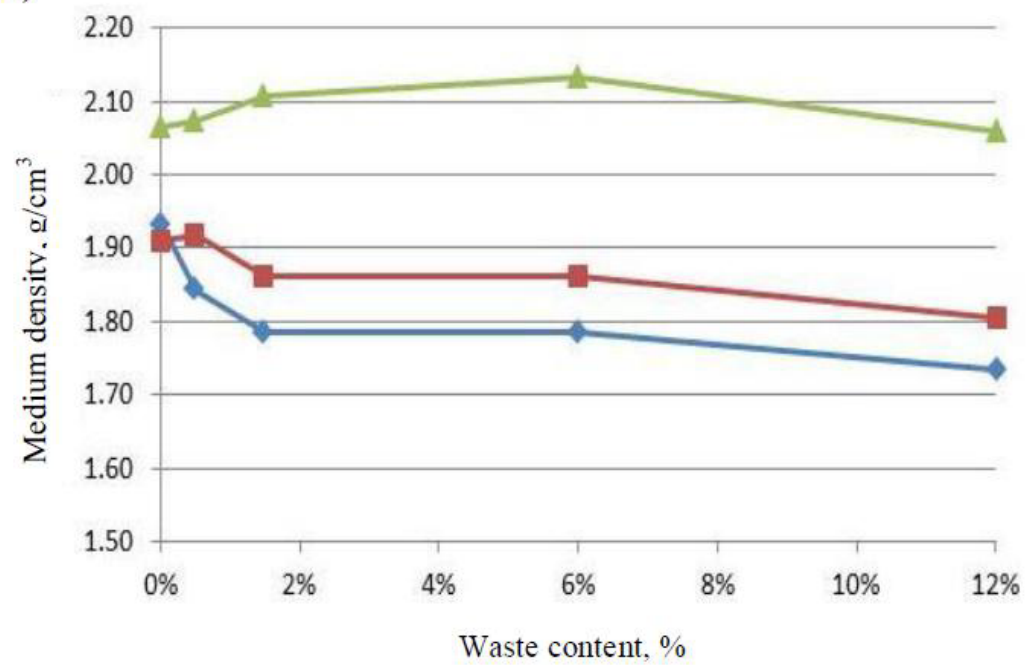

Fig. 1d. Dependences of water absorption $(a, c)$ and medium density $(b, d)$ of ceramic crock based on fusible clay on the waste and (waste $+10 \% \mathrm{Na}_{2} \mathrm{O}$ ) dosage levels and burning rate.

a)

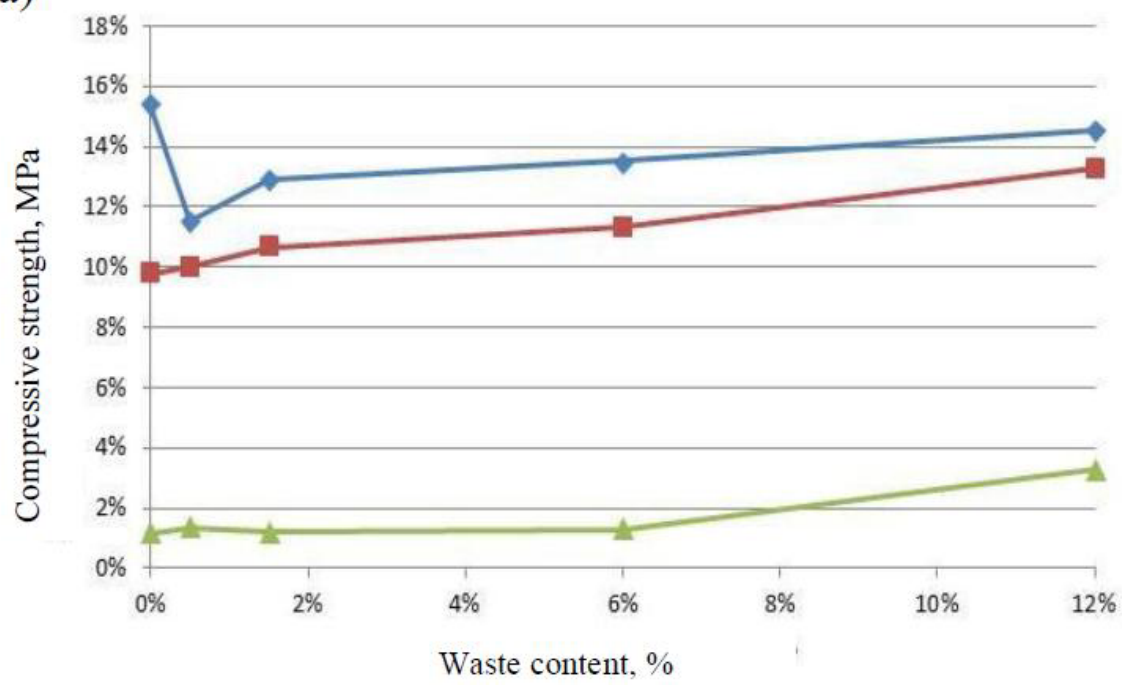

Fig. 2a. Dependences of compressive strength of ceramic crock based on fusible clay on the waste and (waste $+10 \% \mathrm{Na}_{2} \mathrm{O}$ ) dosage levels and burning rate. 
b)

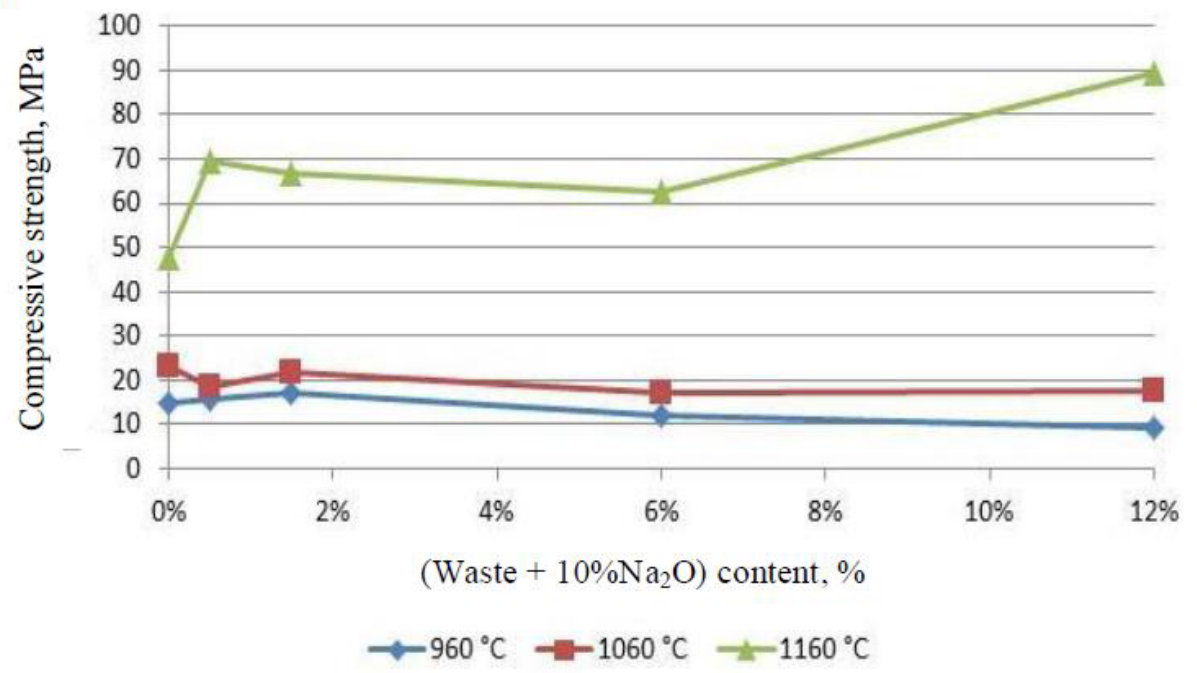

Fig. 2b. Dependences of compressive strength of ceramic crock based on fusible clay on the waste and (waste $+10 \% \mathrm{Na}_{2} \mathrm{O}$ ) dosage levels and burning rate.

Presented in Figure 1a dependencies shows that the introduction of small dosage of waste $(0.5 \mathrm{wt} . \%)$ and at a temperature of $960{ }^{\circ} \mathrm{C}$ reduces water absorption value of ceramic crock samples from 15.4 to $11.5 \%$ (at $25.32 \%$ ). With further increase in waste dosage to $1.5,6,12 \%$ water absorption value of samples slightly increases but remains smaller than the composition without waste.

Increasing the burning temperature to $1060^{\circ} \mathrm{C}$ and waste content from 0.5 to $12 \%$ resulting in an almost linear increase in water absorption from 9.8 to $13.3 \%$. It can be noted that at low burning temperatures $\left(960\right.$ и $\left.1060^{\circ} \mathrm{C}\right)$ waste is hardly comes into solid-phase transformation of clay minerals and products of their destruction.

Apparently, at these temperatures there is no formation of crystalline growths and a sufficient amount of the glass phase, the formation of which would reduce the water absorption.

The situation changes dramatically when the burning temperature increases to $1160{ }^{\circ} \mathrm{C}$. At a dosage of $6 \%$ waste water absorption of samples maintained at approximately $1 \%$. Further increase in the dosage of $12 \%$ water absorption increases to $3.3 \%$. Consequently, one of the effective methods of water absorption regulation is increasing of burning temperature. Increasing it from 960 to $1060{ }^{\circ} \mathrm{C}$ leads to a reduction of water absorption value about $1.15-1.2$ times, and to $1160{ }^{\circ} \mathrm{C} 8$ times. Increasing burning temperature from 1060 to $1160^{\circ} \mathrm{C}$ reduces water absorption value in 4-8.7 times.

A similar effect on the water absorption of the samples has an additive in the batch (waste $+10 \% \mathrm{Na}_{2} \mathrm{O}$ ), depending on which are shown in fig. 1b. Comparison of the influence of waste and (waste $+10 \% \mathrm{Na}_{2} \mathrm{O}$ ) on the properties of the samples shows existence of some differences. At $960{ }^{\circ} \mathrm{C}$ of burning temperature and content of (waste + $10 \% \mathrm{Na}_{2} \mathrm{O}$ ) in $0.5 ; 1.5,6,12 \mathrm{wt} \%$ of clay decrease water absorption value, respectively, to $18.83,17.53,2.59$ and $10.38 \%$. When $1060{ }^{\circ} \mathrm{C}$ for samples with (waste $+10 \% \mathrm{Na}_{2} \mathrm{O}$ ) observed a linear increase in water absorption from 9.8 to $14.3 \%$. A further increase in temperature to $1160{ }^{\circ} \mathrm{C}$ insignificantly changes water absorption value.

In this section, it can be draw the following conclusion: the nature of the dependence of water absorption of crock on the amount of the admixture in the form of (waste $+10 \%$ $\mathrm{Na}_{2} \mathrm{O}$ ) is almost identical to the same curve with the addition of waste. Although the level 
of curves slightly higher in samples with (waste $+10 \% \mathrm{Na}_{2} \mathrm{O}$ ). Consequently, the saturation of waste with alkaline ingredient is not helping to reduce water absorption, though it should be expected, because $\mathrm{Na}_{2} \mathrm{O}$ should promote the formation of the glass phase during burning operation and more, through this, to reduce water absorption and increase the strength of the crock.

These water absorption of the samples correlated with indicators of density (Figure 1c, d), and the compressive strength (Figure 2) of crock.

When $960^{\circ} \mathrm{C}$ (Fig. 1 c, d) on both additives with increasing dosage of 0 to $12 \%$ reduction in density is observed: with waste - from 1.91 to $1.81 \mathrm{~g} / \mathrm{cm}^{3}$, with (waste $+10 \% \mathrm{Na}_{2} \mathrm{O}$ ) from 1.88 to $1.74 \mathrm{~g} / \mathrm{cm}^{3}$

When $1060^{\circ} \mathrm{C}$ on both additives with increasing dosage of 0 to $12 \%$ reduction in density is observed: with waste - from 1.93 to $1.73 \mathrm{~g} / \mathrm{cm}^{3}$, with (waste $+10 \% \mathrm{Na}_{2} \mathrm{O}$ ) - from 1.80 to $1.65 \mathrm{~g} / \mathrm{cm}^{3}$

The highest density of crock $\left(2.13 \mathrm{~g} / \mathrm{cm}^{3}\right)$ is achieved with a $6 \%$ waste at $1160{ }^{\circ} \mathrm{C}$. This is probably due to the fact that the refractory additive in the form of waste catalyst starts to sintered at higher temperatures than 960 , and $1060{ }^{\circ} \mathrm{C}$.

The greatest interest is the effect of waste content depending on the strength of the samples (Fig. 2). It was found that under $960{ }^{\circ} \mathrm{C}$ burning temperature nature of change in strength with increasing addition of both additives of up to $12 \%$ identical. Compared with the control compound strength extremely increase with doses of $0.5,1.5$ and $6 \%$ of $6 \%$ respectively to $24.49,29.93$ and $8.84 \%$.

For compound modified with (waste $+10 \% \mathrm{Na}_{2} \mathrm{O}$ ) the increase in strength is achieved at 0.5 and $1.5 \%$ respectively to 8.84 and $18.36 \%$, and then reduced at 6 and $12 \%$ respectively to 8.16 and $37.41 \%$. At dosage levels of up to $6 \%$ crock strength hardly changes, since It ranges from 23.3 to $23.8 \mathrm{MPa}$; a further increase to $12 \%$ additive reduces the strength to $13.5 \mathrm{MPa}$ (at $71.85 \%$ ). Replacement waste to (waste $+10 \% \mathrm{Na}_{2} \mathrm{O}$ ) in the whole range of strength hardly changes (from 17.7 to $23.2 \mathrm{MPa}$ ).

The strength parameters changes dramatically with increasing burning temperature up to $1160^{\circ} \mathrm{C}$. The introduction of both additives improves the strength over the whole range of doses from 0 to $12 \%$. However, for both additives at $0.5 \%$ there is an abrupt increase in strength: with waste from $47.7 \mathrm{MPa}$ to $87.4 \mathrm{MPa}\left(83.22 \%\right.$ ); with (waste $+10 \% \mathrm{Na}_{2} \mathrm{O}$ ) from 47.7 to $69.4 \mathrm{MPa}(45.49 \%)$. In the interval $(1.5-12 \%)$ of waste dosage strength of the samples remains above the nonmodified samples to $28.72-56.81 \%$ and equal to $61.4-74.8$ $\mathrm{MPa}$. The strength of the samples in the interval of dosage (0.5-6\%) (waste $+10 \% \mathrm{Na}_{2} \mathrm{O}$ ) is not changing significantly and is at the level of $60-70 \mathrm{MPa}$, while $12 \%$ of the additive is increased to $90 \mathrm{MPa}$, which is higher than the control at $87.63 \%$ or almost two times.

Thus, it can be argued that due to the introduction on fusible clay additives waste or (waste $+10 \% \mathrm{Na}_{2} \mathrm{O}$ ) in the range from 0.5 to $12 \mathrm{wt} \%$ from the consumption of clay, you can purposefully adjust the changes of water absorption, the average density and strength of burned samples. It was found that the best properties of samples with both additives is maintained at the burning temperature $1160^{\circ} \mathrm{C}$.

The optimal dosage of waste equal to $0.5 \mathrm{wt} \%$, provides the highest strength of the crock $(87.41 \mathrm{MPa})$, and for (waste $\left.+10 \% \mathrm{Na}_{2} \mathrm{O}\right)-12 \%(89.52 \mathrm{MPa})$.

Such a high strength of the ceramic crock is allowed to produce based on the developed optimum furnace feed composition with waste or (waste $+10 \% \mathrm{Na}_{2} \mathrm{O}$ ) samples of the facing clinker tiles and brick stamps in strength "500", "600", "700".

For evaluating the environmental friendliness of the developed materials in the control samples was determined the content of Cr (VI). Results are presented in Eable 4. 
Table 4. Content of Cr (VI).

\begin{tabular}{|c|c|c|c|c|c|}
\hline №.№ & Composition & $\begin{array}{c}\text { Burning } \\
\text { temperature, } \\
{ }^{\circ} \mathrm{C}\end{array}$ & $\begin{array}{c}\text { Content of } \\
\text { Cr (VI) } \\
\text { mg/g }\end{array}$ & $\begin{array}{c}\text { The efficiency } \\
\text { of } \\
\text { encapsulation } \\
*\end{array}$ & $\begin{array}{l}\text { Exceeding of } \\
\text { maximum } \\
\text { residue limit } \\
(0.05 \mathrm{mg} / \mathrm{g})\end{array}$ \\
\hline 1 & $100 \%$ clay & 960 & 0.156 & 160 & 3.12 \\
\hline 2 & $100 \%$ clay & 1060 & 0.133 & 188 & 2.66 \\
\hline 3 & $100 \%$ clay & 1160 & 0.078 & 320 & 1.56 \\
\hline 4 & $\begin{array}{l}99.5 \% \text { clay }+ \\
0.5 \% \text { waste }\end{array}$ & 1160 & 0.059 & 424 & 1.18 \\
\hline 5 & $\begin{array}{l}99.5 \% \text { clay }+ \\
1.5 \% \text { waste }\end{array}$ & 1160 & 0.142 & 176 & 2.9 \\
\hline 6 & $\begin{array}{l}99.5 \% \text { clay }+ \\
6.0 \% \text { waste }\end{array}$ & 1160 & 0.102 & 245 & 2.04 \\
\hline 7 & $\begin{array}{l}99.5 \% \text { clay }+ \\
12.0 \% \text { waste }\end{array}$ & 1160 & 0.244 & 102 & 4.88 \\
\hline 8 & $\begin{array}{l}88.0 \% \text { clay }+ \\
12.0 \%(\text { waste } \\
\left.+10 \% \mathrm{Na}_{2} \mathrm{O}\right)\end{array}$ & 1160 & 0.161 & 155 & 3.22 \\
\hline
\end{tabular}

The efficiency of encapsulation is the ratio of the concentration of $\mathrm{Cr}$ (VI) in waste, equal to $25 \mathrm{mg} / \mathrm{g}$, the content of $\mathrm{Cr}(\mathrm{VI})$ in the burned samples.

When you consider that in the waste concentration of $\mathrm{Cr}(\mathrm{VI})$ is $25 \mathrm{mg} / \mathrm{g}$, i.e. Exceeding OF maximum residue limit a hundred times, at the expense of their introduction in the composition of the fusible clay in the amount of (0.5-12) wt.\% from the consumption of clay and subsequent encapsulation in the body of burned ceramic samples, the content of $\mathrm{Cr}$ (VI) is reduced in 102-424 times.

From the data in table 4 shows that the presence of $\mathrm{Cr}$ (VI) was detected in all samples, even those which was not modified with waste or (waste $+10 \% \mathrm{Na}_{2} \mathrm{O}$ ). Apparently, in fusible clay inclusions in form $\mathrm{Cr}$ (VI) not fully capsuled in the crock even in the temperature range $1160^{\circ} \mathrm{C}$. In addition, for samples on the basis of a mix of pure lowmelting clays with increasing burning temperature from $960^{\circ} \mathrm{C}$ to $1160^{\circ} \mathrm{C}$ almost twice reduces the content of $\mathrm{Cr}$ (VI). In all samples, burned at $960-1160^{\circ} \mathrm{C}$, the content of $\mathrm{Cr}(\mathrm{VI})$ in 2-4 times exceeds the standard maximum residue limit.

A somewhat different pattern is observed with the introduction of waste. The increase in the dosage of waste from $1.5 \%$ to $12 \mathrm{wt} . \%$ promotes an increase in $\mathrm{Cr}$ (VI) in samples from 0.142 to $0.244 \mathrm{mg} / \mathrm{g}$ or 1.72 times. Replacement additive $12 \%$ of waste by $12 \%$ of (waste $+10 \% \mathrm{Na}_{2} \mathrm{O}$ ) contributes to some reduction in the level of $\mathrm{Cr}$ (VI) from 0.244 to $0.161 \mathrm{mg} / \mathrm{g}$, or 1.52 times.

This is probably due to the presence in waste fluxing ingredient in the form of $\mathrm{Na}_{2} \mathrm{O}$, which during burning contributes to the additional formation of the glass phase, resulting in an increased density of the paste and due to this, the increase of the efficiency of encapsulation of $\mathrm{Cr}$ (VI) in the body of burnt clay. However, the level of Cr (VI) in this case exceeds the norm of maximum residue limit.

Therefore, further adjustment and optimization of the composition, for example by the additional introduction of refractory clay, which should contribute to the formation of dense ceramic material and thus to increase the efficiency of encapsulation of $\mathrm{Cr}$ (VI).

In addition, the obtained results require clarification of the causes and mechanisms of insufficient encapsulation of $\mathrm{Cr}$ (VI) in the crock based on fusible clay, modified by waste and (waste $+10 \% \mathrm{Na}_{2} \mathrm{O}$ ). So, for example, by using XRD and scanning electron microscopy it is necessary to explore structural changes in the burnt samples. 


\section{Conclusions}

1. It is established that due to the introduction on the clay composition waste and (waste $+10 \% \mathrm{Na}_{2} \mathrm{O}$ ) and changing burning temperature can be specifically controlled physical and mechanical properties of ceramic samples.

2. It is proved that the best properties of ceramic samples can be achieved at the burning temperature $1160 \mathrm{oC}$. The greatest strength of the samples is provided by the introduction of $0.5 \%$ waste $-87.41 \mathrm{MPa}$ and $12 \%$ (waste $+10 \% \mathrm{Na} 2 \mathrm{O})-89.52 \mathrm{MPa}$. This higher then strength of the control specimens at $83.17 \%$ of $87.59 \%$, respectively.

3. With the introduction of the charge is $0.5 \%$ of both additives is observed an abrupt increase in strength: for waste from $47.7 \mathrm{MPa}$ to $87.4 \mathrm{MPa}(83.22 \%)$ and from 47.7 to 69.4 MPa (45.49\%) for (waste+10\% Na2O).

4. In low-temperature burning (960-1060oC) introduction of both additives of from 6 to $12 \%$ almost not effective, since at these temperatures the average density of the samples tends to decrease and water absorption increases. Thus, the dosage of waste in the interval $(0.5-6.0) \%$ can be used to improve the strength of samples of $10-30 \%$ and minor the purpose of waste disposal while maintaining the physical and mechanical properties of the samples. The dosage level of waste greater than $12 \%$ reduces the formability of the samples.

5. In all samples content of $\mathrm{Cr}$ (VI) exceeds standard requirements of the maximum residue limit of $0.05 \mathrm{mg} / \mathrm{g}, 1.18-4.88$ times, and the efficiency of encapsulation of waste in the annealed ceramics is $102-424$ times.

6. Introduction the composition of the batch of waste from $1.5 \%$ to $12 \mathrm{wt} . \%$ promotes an increase in $\mathrm{Cr}$ (VI) content in samples from 0.142 to $0.244 \mathrm{mg} / \mathrm{g}$ (1.72 times compared with the control samples).

7. Introduction of $12 \%$ (waste $+10 \% \mathrm{Na} 2 \mathrm{O}$ ) contributes to some reduction in the level of $\mathrm{Cr}$ (VI) from 0.244 to $0.161 \mathrm{mg} / \mathrm{g}$ (1.52 times) due to the presence in waste fluxing ingredient in the form of $\mathrm{Na}_{2} \mathrm{O}$, which during burning contributes to the additional formation of the glass phase, to increase the density of the paste and due to this, efficiency of encapsulation of $\mathrm{Cr}$ (VI) in the body of burnt clay. However, the level of $\mathrm{Cr}$ (VI) in this case exceeds the norm of maximum residue limit, so it requires further adjustment and optimization of the compositions.

The work is executed at support of the Ministry of education of the Russian Federation.

\section{References}

1. D. Vyshegorodskih, J. Ural market of metals, 8 (2005)

2. A. I. Khlystov, V. A. Bozhko, S.V. Sokolova, R.T. Riasov, Successes of modern science, 2 (2004)

3. H. Kinoshita, Advanced Radioactive Waste Conditioning Technologies, 1 (2011)

4. M. I. Safiullin, A.V. Wahine, S.N. Stepin, Bulletin of KSTU, 11 (2011)

5. Sh. Song, A. M. Garbers-Craig, Journal of the European Ceramic Society 36, 6 (2016)

6. M. Doynov, T. Dimitrov, S. Kozhukharov, Boletín de la Sociedad Española de Cerámica y Vidrio, 55, 2 (2016)

7. G.E. Bekmukhamedov, A.A. Lamberov, S.R. Egorova, B.M. Gabidullin, International Journal of Pharmacy \& Technology, 8, 4 (2016)

8. A. V. Vahini, I. V. Usmanov, A. P. Svetlanov, S. N. Stepin, Paintwork materials and their application, 574, 10 (2008) 
9. R. Galindo, C. Gargori, N. Fas, M. Llusar, G. Monrós, Ceramics International 41, 5 (2015)

10. Y. V. Tokarev, Abstracts of the 60th jubilee of the Republican scientific conference, 8 (2008)

11. N.R. Rakhimova, R.Z. Rakhimov, N.I. Naumkina, Y.N. Osin, Cement and Concrete Composites, 72 (2016)

12. Patent RF 2462431, Declared 24.01.11, Published 27.09.2012, Bulletin № 18

13. V.S. Izotov, R.Kh. Mukhametrakhimov, A.R. Galautdinov, Stroitel'nye Materialy 725, 20 (2015)

14. R.Kh. Mukhametrakhimov, V.S. Izotov, Stroitelnye materialy, 710, 116 (2014)

15. V.S. Izotov, R.Kh. Mukhametrakhimov, A.R. Galautdinov, Stroitel'nye Materialy 740, 70 (2016) 